Seyahat ve Otel İşletmeciliği Dergisi/

Journal of Travel and Hospitality Management

16 (3), 2019, 493-514.

Gönderim Tarihi: 09.09.2019

Kabul Tarihi:05.11.2019

\title{
Yalnız Seyahat Eden Kadınların Seyahat Deneyimleri
}

\section{Travel Experiences of Solo Female Travelers}

Elif ASLANTÜRK

Mersin Üniversitesi

Sosyal Bilimler Enstitüsü

E-posta: elif87aslanturk@hotmail.com
Doç. Dr. Kamil UNUR

Mersin Üniversitesi

Sosyal Bilimler Enstitüsü

E-posta:kunur@mersin.edu.tr

Öz

Bu çalışmada temel olarak kadınların yalnız seyahat deneyimleri ele alınmaktadır. Bu kapsamda araştırmanın temel amacı kadınların neden yalnız seyahat ettikleri, destinasyon seçim kriterlerinin neler olduğu ve seyahat sırasında ne yaşadıklarını, yani seyahat deneyimlerini belirlemektir. Belirlenen amaç doğrultusunda nitel veriler yapılandırılmış görüşme formuyla elde edilmiştir. Örneklem seçiminde amaçlı ve kartopu örnekleme tekniği kullanılarak, 33 kadın katılımcıdan veri toplanmıştır. Veriler içerik analizi ve betimsel analize tabi tutulmuştur. Araştırmadan elde edilen bulgular neticesinde, yalnız seyahat eden kadınların, özgür/bağımsız olma, kendilerini keşfederek yenilenme amacıyla ve yalnız olma isteği ile seyahatlere başladıkları sonucuna ulaşılmıştır. Yine araştırma sonuçları, destinasyon seçimindeki en önemli faktörün güvenlik olduğunu göstermiştir. Ayrıca yalnız seyahat etmenin risklerine rağmen kişisel gelişim, yeni dostluklar edinme, yerel halkın olumlu desteği gibi olumlu faktörlerin etkisiyle de kadınların cesaret kazandıkları ve yalnız seyahat etmeye devam edecekleri sonucuna ulaşılmıştır.

Anahtar Kelimeler: Yalnız seyahat, yalnız kadın gezginler, deneyim, turizm

\section{Abstract}

This study mainly deals with women's experiences of traveling alone. In this context, the main purpose of the study is to determine why women travel alone, what are the criteria for destination selection and what they experience during travel. Qualitative data were obtained from 33 women via a structured interview form. Purposive and snowball sampling techniques were used. The data were subjected to the content and the descriptive analysis. The findings of the study revealed that women started traveling alone with the desire to be free / independent, to discover themselves and to be alone. The research findings also showed that security is the most important factor in destination selection. As a result, despite the risks of traveling alone, it was concluded that women gained courage and would continue to travel alone due to positive factors such as personal development, acquiring new friendships and positive support from local people.

Key Words: Solo travel, Female solo travelers, experiences, tourism 


\section{Giriş}

Son yıllarda tüm dünyada genel olarak küreselleşme olarak adlandırılan ama özelde ise bilişim ve ulaşım teknolojilerinde yaşanan gelişmeler, yalnız seyahatlerin sayısında artışlara yol açmıştır. Çünkü artık internet sayesinde neredeyse her destinasyon hakkında gerekli bilgilere ulaşmak ve seyahat için gerekli düzenlemeleri yapmak olanaklı hale gelmiştir. Hostelworld, 2015 - 2017 yılları arasında yapılan yalnız rezervasyon sayısında \%42 artış olduğunu, Airbnb de yalnız rezervasyon sayılarında artış yaşandığını (The Telegraph, 2018), TUYED (2016) tek kişilik seyahatleri \% 58.3 ile kadın gezginlerin daha çok tercih ettiğini ortaya koymuştur. British Airways'in 2018 yılındaki araştırması da dünya genelinde kadınların \%50'sinin tek başına tatile çıktığını, \%75'inin de çıkmayı planladığını belirtmiştir (Media Centre British Airways, 2018). Yalnız seyahatlerde her ne kadar artışlar yaşansa da kadınlar erkeklere kıyasla daha dezavantajı bir durumdadır. Çünkü hala kadınlar yalnız seyahat ederken cinsel taciz, istenmeyen ilgi gibi cinsiyete dayalı risklere maruz kalmaktadır (Wilson ve Little, 2008; Jordan ve Gibson, 2005). Bu bağlamda, Berdychevsky ve Gibson (2015) uygulanan toplumsal baskı ve tüm cinsel risk unsurlarının erkeklerin turizm deneyimlerini ayrıcalıklı kıldığını, turizm alanı ve uygulamalarının da cinsiyete dayalı çifte standartları işaret ettiğini belirtmişlerdir. Bu durum, yani yalnız seyahatler geçmişte kadınlar açısından erkeklere kıyasla çok daha zordu. Nitekim turizm faaliyetlerine katılımda kadınlar için yalnız seyahat etmek geçmiş dönemlerde uygunsuz bir davranış ve eylem olarak nitelendirilmiştir (Jordan ve Gibson, 2005; Wilson ve Little, 2005). Kısacası toplumsal cinsiyet rolleri, bireylerin yaşamlarının her yönünü etkilediği gibi turizm ve boş zaman etkinliklerine katılım şanslarını da etkilemektedir (Jordan ve Gibson, 2005).

Günümüzde küresel seyahatler ve turizm faaliyetlerinin çoğunlukla erkeklerin öncülüğünde olduğuna işaret eden durumlara rağmen, kadınlar da turizm faaliyetlerine katılımda yadsınamayacak bir görünüme sahiptir (Bond, 1997; Myers ve Mondcrief, 1978). Yang ve arkadaşları (2017) yaşanan olumlu gelişmeler ile birlikte kadınların tarihsel süreç içerisinde seyahat etme konusunda giderek daha fazla fırsata ve seçime sahip olduğunu ve bu nedenle de günümüzde artan sayıda kadının; özerklik ve bağımsızlık gibi yeni kazanılmış hakları kucakladığını ve daha da güçlenebilmek için yalnız seyahatler yaptığını belirtmektedir. Günümüzde cesur, kendine güvenen ve maceracı kadınlar bir seyahat çağrısını duyduklarında, bir eş, arkadaş veya bir başka neden aramaksızın bağımsız seyahat edebilmektedir (Wilson, 2004; Bond, 1997). Bianchi (2016) yalnız seyahat eden kadınların sayısındaki artışı özellikle değişen demografik yapılara bağlamaktadır.

Demografik yapı değişimlerinden, insanların uzun süre bekâr kalmaları, yaşlanan nüfusun giderek daha aktif hale gelmesi ve yaşam tarzlarındaki değişikliklerin seyahat kararlarını ve taleplerini etkilediğini (Valaja, 2018:5), yaşam tarzında değişim yaşayan kadınların da yeni bir gezgin grubunu temsil ettiğini söylemek mümkündür. Bu bağlamda, Goodwin ve Lockshin (1992) geleneksel olarak arkadaş ya da aile üyeleriyle paylaşılan tüketim etkinliklerinin yerine yalnız kalmayı tercih eden bir eğilime işaret etmiştir. Bond (1997) ise boşanmış (dul) ya da eşi olmayan kadınların evde kalmayıp, yalnız olarak, gruplar halinde veya arkadaşlarıyla birlikte gezilere çıkmakta ve yıl içerisinde çok sayıda uzun yolculuklar yapmakta olduğunu ortaya koymuştur. Bu durum yalnız kadın gezginlerin büyüyen, etkili bir pazar bölümünü temsil ettiğine işaret etmektedir (Wilson, 2004:4). Bir başka ifadeyle, çeşitli sebeplerden dolayı bağımsız bir şekilde seyahat eden kadınların faaliyetlerinin ve turistik ürün ve hizmetlerin tüketimine ilgisinin artması bu pazarın küresel ekonomide önem kazanmasına neden olmaktadır (Carvalho ve diğ., 2014:31). 
Valaja (2018:8) kadınların, 1970'lerin sonlarında ve 1980'lerin başında turist olarak turizm araştırmalarına konu olmaya başladıklarını ve kadınların seyahat tecrübesi ile ilgili araştırmaların ve literatürün bu dönemlerde ortaya çıktığını belirtmiştir. Yapılan literatür taraması sonucunda, yalnız seyahat eden kadınların, seyahatlerine yönelik sınırlı sayıda araştırma, özellikle kadınların "yalnız seyahat deneyimlerini", turizm bağlamında araştırmıştır (Wilson ve Little, 2005; Bond, 1997). Uluslararası alanyazında yalnız seyahat eden kadınların seyahatlerine yönelik çalışmalarda çoğunlukla kadınların seyahat motivasyonları ve seyahat kısıtlamaları incelenmiştir (Bianchi, 2016). Türkçe alanyazında ise, konu ile ilgili mevcut çalışmaların yetersizliğine yanıt olarak bu çalışma, yalnız seyahat eden kadınların seyahat deneyimlerini araştırmak amacıyla yapılmıştır. Çalışma sonuçlarının konuya dikkat çekerek alanyazındaki boşluğun doldurulmasına katkı sağlayacağı düşünülmektedir.

\section{Kadınların Yalnız Seyahat Hareketleri}

Kadınların yalnız seyahatlerinin başlangıcı tam olarak bilinmemekle birlikte, ilk bilinen kadın gezginlerin Kudüs'e ve Kutsal Topraklara seyahat eden hacılar olduğu söylenmektedir. 18. ve 19. yüzyıllarda ise, gezgin ve gezginlik rollerinin temel olarak erkeklere verilmiş olması ve dünyayı keşfetme kavramının da yoğun bir şekilde erkekleştirilmesi nedeniyle kadın gezginlerin bu dönemlerde toplumsal kısıtlamalarla karşılaştıkları söylenebilir (Valaja, 2018:7).

İkinci Dünya Savaşı'ndan önce kadınların boş zaman etkinliklerine katıımı sınırlıyken (Marzuki ve diğ., 2012:149), İkinci Dünya Savaşı'ndan sonra çocuksuz ve bekar kadınların sayısı artmış (Collins ve Tisdell, 2002), kadınlar eğitim ve istihdama erişim kazanarak finansal bağımsızlık elde etmiş (Valaja, 2018:8; Yang ve diğ., 2017b), bu durumda kadınların seyahate olan ilgilerinin de artmasıyla sonuçlanmıştır.

Yeni bir seyahat pazarı olan ve Bond'un (1997) 'yalnız kadın gezginler' olarak adlandırdığı kadınlar için yapılan ilk turlar alışveriş gezileri şeklinde yapılmıştır. Zamanla kadınların turistik ürün ve hizmetlerin tüketimine ilgisinin artması tatil ve iş seyahatlerinde de kadınların gücünü arttırmış ve küresel ekonomide önemli olmasını sağlamıştır (Carvalho ve diğ., (2014) Bu gelişmeler, toplumun kadına karşı değişen ve ilerleme kaydeden tutumuna, daha iyi işlere, yükselen mevkilere, bağımsız çalışan kadın kesimine, geç evliliklere, ahlaki duygu teorisinin değişen doğasına ve eşler arasındaki ailevi sorumlulukların ortak paylaşımı gibi unsurlara dayandırılabilir (Khan, 2011).

Kadınların yalnız seyahatlere yönelmelerini Gray ve Kerstetter (2001) sosyokültürel alanda, eğitimde ve ekonomik anlamda yaşanan değişimlerde meydana gelen olumlu sonuçlara, Khoo-Lattimore ve Prayag (2015) ise kadınların işgücüne yönelik artan katkılarına bağlamıştır. Ayrıca değişim gösteren sosyal ve politik koşulların etkisiyle de eş, anne, kız arkadaş veya ev kadını gibi karmaşık kimliklerinden uzaklaşan kadınlar, kendi zevkleri ve memnuniyetleri peşinde tek başlarına turist olma fırsatını yakalamışlardır (Kaba ve Emekli, 2018; Myers 2010:215).

Ekonomik, sosyal ve boş zamana yönelik bağımsızlıklarına bağlı olarak daha fazla özgür alana ve daha fazla seçeneğe sahip olan kadınlar için seyahat etmek, bir tür kısıtlamalarla mücadele stratejisi olarak da görülmektedir (Tilley ve Houston, 2015). Günümüzde hala dünyanın belli bölgelerinde kadınlara yönelik mevcut kısıtlamaların olmasına rağmen, kadınların çağdaş seyahat pazarının yarısını oluşturduğu söylenebilir (Valaja, 2018:8; Yang ve diğ., 2017b). Örneğin; İran'da 18 yaşını doldurmuş bekâr kadınlar babalarının izin vermesi koşuluyla pasaport alabilmekte; evli 
kadınlar ise, kocalarının izni olmadan yurt dışına çıkamamaktadır (Tonga, 2019). Suudi Arabistan'da kadınlar aileden bir erkeğin izni olmadan pasaport alamıyor ve seyahat edemiyordu. Ancak Suudi Arabistan Krallığı, 2 Ağustos 2019 tarihinden itibaren 21 yaş ve üzeri kadınlara ailelerinden bir erkek refakatçi olmadan tek başlarına yurt dışına çıkabilmelerine izin verdi (Illerihaber, 2019).

\section{Kadınları Yalnız Seyahate İten Nedenler ve Seyahat Deneyimleri}

Geç evliliklerin ve bekâr sayısının artması, çocuk sayısının kontrol altına alınması ya da çocuk sahibi olmama, boşanma oranlarındaki artış gibi ailenin geleneksel ideolojilerinin kayması ve kadınların işgücüne katılımının artmasıyla birlikte kadınların finansal durumu iyileşmiş ve bu durum da kadınların bağımsız olmaları için güç unsuru oluşturmuştur (Marzuki ve diğ., 2012:149; Lin ve Lehto, 2006). Wilson ve Little (2005) demografik değişimlerle birlikte kadınların beklentilerindeki psikolojik değişim, benlik saygısı, bireyin bir eşe sahip olmaktan ve evlenmekten ziyade işinde başarılı olması ve tatilden memnun kalma isteğinden kaynaklanan beklentiler sonucu bu değişimin kaçınılmaz olduğunu belirtmiştir. Turizm de bu bağlamda, kadınların sosyal ve finansal özerkliklerini yaşayabilecekleri/uygulayabilecekleri alanlardan biri olarak görülmektedir (Marzuki ve diğ., 2012:149-150; Lin ve Lehto, 2006). Ayrıca bu nedenler, geleneksel olarak arkadaş ya da aile üyeleriyle paylaşılan tüketim etkinliklerinin yerine yalnız kalmayı tercih eden bir eğilimi de işaret etmektedir (Goodwin ve Lockshin, 1992).

Literatürde genel olarak yalnız ve bağımsız seyahat eden kadınları seyahate iten nedenler; kendine meydan okumak, yeni insanlarla tanışmak, kişisel konfor alanlarının ötesine geçmek, otonomi ve bağımsızlık hissini geliştirmek, kendini güçlendirmek ve kendi alanlarını genişletmek (Pereira ve Silva, 2018; McNamara ve Prideaux, 2010), yeni yerler ziyaret etme ve kişisel ve sosyal faktörler, (Laesser vd., 2009) stresten kaçma, yenilenme ve özerklik (Laing ve Crouch, 2009), özgürleşme, bireysel seyahatin çekiciliği ve rutin hayattan kaçış, özgüven, rahatlama, merak ve sınırların görülmesi ve aşılması (Pekiner, 2019:47-48) şeklinde sıralanmaktadır. Ayrıca kadınlar için, yalnız seyahat etme öz gelişim ve öz büyümenin bir kaynağı olarak görülmekte ve tek başlarına üstlendikleri tatil deneyimleri onlar için bir gurur kaynağı olmaktadır (Bianchi, 2016). Bu nedenlerle seyahat eden kadınlar ayrıca bu deneyimleri, unutulmaz seyahat deneyimi olarak da görmektedir (Pereira ve Silva, 2018).

Yang ve arkadaşları (2018) Asyalı kadınların seyahatleri sırasında turizm alanlarında cinsiyetçiliğe ve ırk ayrımcılığına dayalı risklerle karşılaştıklarını, cinsel risklerle ilgili olumsuz deneyimlerin kadınlara güçlendirme duygusu kazandırdığını; Pekiner (2019) kadınların yalnız seyahatlerinde otostop çekerken ve otogarda yalnız dolaşırken yaşadıkları bir kaç cinsel taciz dışında genelde özgüvenlerinin gelişmesi, yeni yerler görüp yeni arkadaşlıklar kurmak, yeni yemekler tatmak, yeni etkinliklere katılmak gibi birçok olumlu tatil deneyimi yaşadıklarını bulgulamıştır. Valaja (2018:75) bireylerin yalnız seyahat etmedeki risk algılarının, bireysel ve sosyo-kültürel özelliklerden, kişisel olarak edinilmiş bilgilerden, kadınlar ile erkeklerin farklı özelliklerinden (fiziksel veya psikolojik farklılıklar) etkilendiğini; yalnız seyahat eden kadınların, erkeklere kıyasla daha fazla risk altında olduklarına yönelik algılarının olduğunu ve kadınların erkekleri de risk olarak algıladığını (örneğin; toplumda cinsiyet eşitliği ile ilgili gelişmelere bakılmaksızın, kadınların kendilerini en azından fiziksel olarak erkeklerden daha güçsüz olarak algılamaları gibi); kadınların risk unsurlarını ortadan kaldırabilmek için de, tehdit olarak gördükleri erkekleri görmezden gelme ve kendilerini onlar için uygun görünmeyen kişiler olarak sunma şeklinde çeşitli stratejilerinin olduğunu söylemektedir. Kaba ve Emekli (2018) yalnız seyahat eden kadınların destinasyon seçerken dikkat ettikleri öncelikli faktörün, güvenlik olduğunu ve 
risk algısında cinsiyete dayalı risklerin kadınların yalnız seyahate ilişkin algısını ve erişimini etkileyen temel faktör olduğunu; Khan (2011) araştırmasına katılan kadınların $\% 50$ ' sinden fazlasının seyahat etmede cinsiyetlerini bir kısıtlama olarak gördüklerini ve aile sorumlulukları nedeniyle seyahatlerinin kısıtlanmakta olduğunu; McNamara ve Prideaux (2010) yalnız ve bağımsız kadın gezginlerin bulundukları destinasyonda bölgeyi ziyaret etme motivasyonlarında, homojenlik olmadığını, kendilerini güvende hissettiklerini ve kısmen risk içeren çok çeşitli etkinliklere katıldıklarını; Wilson ve Little (2008) kadınların başkalarının algıları, zarar görmeye yatkınlık, kısıtlanmış erişim duygusu ve dikkat çekme hissine ilişkin seyahat korkuları yaşadıklarını; Wilson ve Little (2005) yalnız kadın gezginlerin kendilerine yönelik kısıtlamaların mevcut olduğunu, yaşamları ve seyahat deneyimleri üzerinde kısıllamaların pek çok şekilde etkisi olduğunu; Bond (1997) ise giderek artan şekilde kadınların eşleri veya erkekler olmadan seyahat ettiklerini, yalnız kadın gezginliğin büyüyen ve etkili bir pazar bölümünü temsil ettiğini, yaşam tarzı değişimleri yaşayan kadınların, kazançlı ve yeni bir gezgin grubunu temsil ettiğini ortaya koyan sonuçlara ulaşmıştır.

\section{Araştırmanın Yöntemi}

Araştırmanın amacı, yalnız seyahat eden kadınların seyahat deneyimlerini araştırmaktır. Çalışmada nitel bir araştırma süreci izlenmiş ve yapılandırılmış görüşme tekniğinden yararlanılmıştır. Yapılandırılmış görüşmelerde, görüşmecinin doğaçlama davranması söz konusu değildir ve soruların hangi sırada sorulacağı önceden belirlenmiştir (Özdemir, 2013:37). Görüşmeye ilişkin soru formu oluşturulmadan önce yalnız seyahatlere ilişkin ayrıntılı literatür taraması yapılmış, Kaba ve Emekli' nin (2018) 'Turizmde Yükselen Bir Eğilim: Yalnız Seyahat Eden Kadın Gezginler' adlı çalışmasında kullanılan soru formunun da incelenmesi sonucu elde edilen bilgiler temel alınarak görüşme soruları oluşturulmuştur. Hazırlanan görüşme soruları turizm alanında uzman dört akademisyenin onayına sunulmuş ve akademisyenlerin yönlendirme ve önerileri doğrultusunda görüşmede kullanılacak olan sorulara son şekli verilmiştir. İki bölümden oluşan görüşme formunda; ilk bölüm demografik özelliklere ilişkin yedi soru, ikinci bölüm ise seyahat deneyimlerine yönelik 14 açık uçlu sorudan oluşmaktadır. Görüşme soruları yalnız seyahat eden kadınların seyahat deneyimlerini ortaya koyacak şekilde ayrıntılı olarak hazırlanmıştır.

Araştırmanın evrenini yalnız seyahat eden Türk kadınları oluşturmaktadır. Görüşmelere katılacak kişilerin belirlenmesinde ise, amaçlı ve kartopu örnekleme tekniği kullanılmıştır. Örneklem seçiminde kullanılan bu teknikte, isteyen herkes örnekleme dahil edilmekte ve veri toplama süreci yeterli örneklem sayısına ulaşıncaya kadar devam etmektedir (Altunışık ve diğ., 2007: 132). Ulaşılan katılımcıların yönlendirmesi ile benzer kişiler çalışmaya dâhil edilerek örneklem grubu oluşturulmuştur. Katılımcıların çoğunun çalışmanın yapıldığı şehrin dışında ya da seyahat halinde olması ve internet aracılığı ile ulaşılabilmiş olması nedeniyle yüz yüze görüşme yapılamamıştır. Bu nedenle görüşme sorularının katılımcılara e-mail ve sosyal medya üzerinden gönderilmesi kararlaştırılmıştır. Veriler 15 Şubat 2019 - 15 Mayıs 2019 tarihleri arasında toplam 33 kadın katılımcıdan toplanmıştır. Araştırmadan elde edilen veriler, içerik analizi ve betimsel analiz tekniklerinden yararlanılarak yorumlanmıştır. İçerik analizi, yazılı metinlerin, görsellerin ya da söylemlerin içeriğine bakılarak, en sık ya da en az hangi kavram, olay ya da düşüncelere vurgu yapıldığına dayalı olarak bir sonuca ulaşılma işlemidir (Kozak, 2014: 138). Betimsel analiz ise, verilerin özgün biçimlerine sadık kalarak, kişilerin söylediklerinden doğrudan alıntılar yaparak veri sunma işlemidir (Kümbetoğlu, 2005:154). Yapılan içerik analizi ve betimsel analiz yöntemleriyle elde edilmiş olan bulgular takip eden başlık altında sunulmaktadır. 


\section{Bulgular}

\subsection{Demografik Bilgiler}

Katılımcıların tamamı Türk'tür. Katılımcıların 24'ü 25-35 yaş grubunda olup 5'i evli ve yalnızca 2'sinin çocuğu vardır. Katılımcıların hepsi en az lisans derecesine sahip ve 18'i orta gelir düzeyinde olduğunu düşünmektedir. Katılımcıların meslekleri; 4 akademisyen, 3 öğretmen, 3 çalışmayan, 1 ihracat uzmanı, 1 dijital pazarlamacı, 1 gazeteci (gezgin kadınlar platformu kurucusu), 1 dans sanatçısı, 1 sosyolog, 1 metin yazarı, 1 bütçe ve raporlama uzmanı, 1 iletişim danışmanı, 1 endüstri ürünleri tasarımcısı, 1 eczacı, 1 insan kaynakları yöneticisi, 1 pazarlamacı, 1 marka müdürü, 1 bankacı, 1 devlet memuru, 1 şehir plancısı, 1 öğrenci, 1 yazar, 1 mimar, 1 yönetici, 1 yapım asistanı, 1 serbest meslek çalışanı ve 1 kabin memuru şeklindedir. Katılımcılara ait demografik bilgiler Tablo 1'de sunulmuştur.

Tablo 1: Katılımcılara İlişkin Demografik Bilgiler

\begin{tabular}{|llll|}
\hline \multirow{2}{*}{ Medeni Durum } & \multicolumn{1}{c}{$\sum$} & $\%$ \\
& Bekâr & 28 & 84,85 \\
\cline { 2 - 4 } & Evli & 5 & 15,15 \\
\hline \multirow{3}{*}{ Eğitim Düzeyi } & Lisans & 15 & 45,45 \\
\cline { 2 - 4 } & Y.Lisans & 17 & 51,52 \\
\cline { 2 - 4 } & Doktora & 1 & 3,03 \\
\hline \multirow{2}{*}{ Yaş Grubu } & Genç (25-35) & 24 & 72,73 \\
\hline \multirow{3}{*}{ Gelir Düzeyi } & Orta yaşı (36-48) & 9 & 27,27 \\
\cline { 2 - 4 } & Düşük & 2 & 6,06 \\
\cline { 2 - 4 } & Orta Altı & 1 & 3,03 \\
\cline { 2 - 4 } & Orta & 18 & 54,55 \\
\cline { 2 - 4 } & Orta Üstü & 11 & 33,33 \\
\hline \multirow{2}{*}{ Yaşadığı Yer } & Yurt İçi & 29 & 87,88 \\
\cline { 2 - 4 } & Yurt Dışı & 2 & 6,06 \\
\hline \multirow{2}{*}{ Çocuklu Olma(ma) Durumu } & Çocuğu Olan & 31 & 93,94 \\
\cline { 2 - 4 } & Çocuğu Olmayan & &
\end{tabular}

\subsection{Kadınları Yalnız Seyahate Teşvik Eden/Iten Nedenlere İlişkin Bulgular}

Katılımcıların yalnız seyahat etme nedenlerine ilişkin içerik analizi bulguları Tablo 2'de sunulmaktadır. Katılımcılar tarafından en çok tekrarlanan ilk neden, 21 tekrarla $(\% 46,67)$ yalnız olma isteğidir.

Tablo 2: Yalnız Seyahate Teşvik Eden/Iten Nedenler

\begin{tabular}{|l|l|l|}
\hline Nedenler & $\Sigma$ & $\%$ \\
\hline Yalnız olma isteği & 21 & 46,67 \\
\hline $\begin{array}{l}\text { Seyahat arkadaşının olmaması } \\
\text { (eş/arkadaş bulamama) }\end{array}$ & 12 & 26,67 \\
\hline $\begin{array}{l}\text { Diğer nedenler } \\
\text { (gelir düzeyindeki farklılık, kişisel beklentilerdeki faklılık, } \\
\text { program ve zaman uyuşmazlığı, ortak zevkleri } \\
\text { paylaşmamak, farklı ilgi alanları vb. nedenler) }\end{array}$ & 12 & 26,67 \\
\hline$\Sigma$ & $\mathbf{4 5}$ & $\mathbf{1 0 0}$ \\
\hline
\end{tabular}


Katılımcıları yalnız seyahat etmeye teşvik eden/iten nedenlerle ilgili bazı ifadeler aşağıda sunulmaktadır.

...iki kişi karar vermeyi sevmiyorum. Aldığım kararların sorumluluğu bende olsun istiyorum... (K5)

...Ben yalnız vakit geçirmeyi seven biri olmama rağmen seyahatlerime hep arkadaşlarımla gitmeye çalıştım. Beraber gezip birlikte keşfedip eğlenmeyi istedim. Ama zaman içerisinde tümüyle bana uyacak arkadaşlar bulmak güçleşti. Evli olanlar eşiyle gitmek istedi, bekâr olanların bir kısmı iznini ayarlayamadı. Çalışmayanlar da maddi durum yüzünden bana katılamadı. Beraber gittiğim arkadaşlarımla büyük sorunlar yaşamamakla beraber hep içime sinmeyen detaylar oldu. Durum böyle olunca yalnız gezi planları yapmaya başladım. Çünkü ben seyahat için büyük maddi ve manevi fedakârlık yapıyorum, bunu hiç kimse için riske atamam.(K18)

...Yalnız seyahat; çoğu zaman bir tercih değil, zorunluluk. Yakın çevrenizde sizin ziyaret etmek istediğiniz ülkeleri ilgi çekici bulan kimse bulamamak, uzun süreli çıkacağınız seyahatlerde zaman sorunu olmayan birini bulmak, sizin gibi dar bütçeyle ve konforsuz gezmeyi kabul edecek birini bulamamak gibi sebepler sizi yalnız seyahat etmeye itebilir. (K8)

\subsection{Kadınların Yalnız Seyahat Etme Amaçlarına İlişkin Bulgular}

Katılımcıların yalnız seyahat etme amaçlarına ilişkin içerik analizi bulguları Tablo 3'te sunulmaktadır. Katılımcılar tarafından en çok tekrarlanan ilk iki neden, 25 tekrarla (\% 46,30) özgür/bağımsız olmak ve 15 tekrarla $(\% 27,78)$ kendini keşfetmek yenilenmektir.

Tablo 3: Yalnız Seyahat Etme Amaçları

\begin{tabular}{|l|c|c|}
\hline Amaçlar & $\Sigma$ & $\%$ \\
\hline Özgür/bağımsız olmak & 25 & 46,30 \\
\hline Kendini keşfetmek -yenilenmek & 15 & 27,78 \\
\hline $\begin{array}{l}\text { Kendini güçlendirmek ve kendi alanlarını } \\
\text { genişletmek }\end{array}$ & 11 & 20,37 \\
\hline Yeni insanlarla tanışma arzusu & 3 & 5,56 \\
\hline$\Sigma$ & $\mathbf{5 4}$ & $\mathbf{1 0 0}$ \\
\hline
\end{tabular}

Katılımcıların yalnız seyahat etme amaçlarına yönelik en sık tekrar edilen bazı ifadeler aşağıda sunulmaktadır.

... Tek başına gezmek özgürlük, çünkü birine "şunu yapmak ister misin?" diye sormak zorunda değilsin. Tek başına seyahat etmek canının istediğini yapabilmek demektir. (K3)

... Arkadaş ile seyahat etmek demek bir anlamda özgürlügünüzün kısıtlanması demek... Yalnızken başka bir pencereden bakıyorsunuz, her daim yeniliklere daha açık ve pozitif oluyorsunuz. Insanlarla daha kolay iletişime geçiyorsunuz ve onlar da sizinle. Yani yalnız seyahat edince aslında hiç yalnız kalmıyorsunuz. (K13) 


\subsection{Destinasyon Seçim Sürecine İlişkin Bulgular}

Katılımcıların yalnız seyahat edecekleri destinasyonları seçerken dikkat ettikleri faktörlere ilişkin içerik analizi bulguları Tablo 4'te sunulmaktadır. Katılımcıların destinasyon seçim sürecinde en çok dikkat ettikleri ve en çok tekrarlanan ilk iki faktör, 17 tekrarla $(\% 28,81)$ destinasyonun güvenlik koşulları ve 15 tekrarla $(\% 25,42)$ destinasyonun popülerliğidir.

Tablo 4: Destinasyon Seçim Sürecinde Dikkat Edilen Faktörler

\begin{tabular}{|l|c|c|}
\hline İfadeler & $\Sigma$ & $\%$ \\
\hline Destinasyonun güvenlik koşulları & 17 & 28,81 \\
\hline $\begin{array}{l}\text { Destinasyonun popülerliği } \\
\text { (doğal, tarihi ve kültürel özellikleri, gelişmişlik düzeyi, yerel halkın tutumu } \\
\text { vb.) }\end{array}$ & 15 & 25,42 \\
\hline Ekonomik uygunluk & 10 & 16,95 \\
\hline $\begin{array}{l}\text { Mesafe/erişilebilirlik } \\
\text { (destinasyon uzaklığı /ulaşım sistemi/gelişmişlik düzeyi) }\end{array}$ & 9 & 15,25 \\
\hline $\begin{array}{l}\text { Diğer gezginlerin tavsiyesi } \\
\text { (destinasyonları ziyaret etmiş olan kadın gezginlerin fikrini alma/blog } \\
\text { sayfaları okuma) }\end{array}$ & 7 & 11,86 \\
\hline Destinasyonun iklim koşulları/mevsimi & 1 & 1,69 \\
\hline$\Sigma$ & $\mathbf{5 9}$ & $\mathbf{1 0 0}$ \\
\hline
\end{tabular}

Katılımcıların yalnız seyahat edecekleri destinasyonları seçerken dikkat ettikleri faktörlerle ilgili bazı ifadeler aşağıda sunulmaktadır.

...Öncelikle güvenlik konusunu önemsiyorum. Gelir düzeyim pek yüksek olmadığı için de maddi durumuma göre de şekil almak zorundayım. Bazen akşam yemeğini bile geçiştirmek zorunda kalabiliyorum. (K1)

...Ucuza seyahat edebileceğim ama kültürünü, doğasını merak ettiğim yerleri seçmeye çalışıyordum... (K9)

\subsection{Ziyaret Edilen Destinasyonlara İlişkin Bulgular}

Katılımcıların yalnız seyahat ettikleri destinasyonlara ilişkin içerik analizi bulgularında en çok ziyaret edilen destinasyonlar; 112 tekrarla $(\% 53,33)$ Avrupa, 55 tekrarla $(\% 26,19)$ Asya, 17 tekrarla $(\% 8,10)$ Güney Amerika, 14 tekrarla $(\% 6,67)$ Kuzey Amerika, 11 tekrarla $(\% 5,24)$ Afrika ve 1 tekrarla $(\% 0,40)$ Okyanusya'dır.

\subsection{Yalnız Seyahat Edilen ve Güvenli Bulunan Destinasyonlara İlişkin Bulgular}

Katılımcıların yalnız seyahat ettikleri destinasyonlardan en güvenli olduğunu belirttikleri destinasyonlara ilişkin içerik analizi bulguları Tablo 5'te sunulmaktadır. Katılımcılar tarafından en güvenli bulunan destinasyonlardan en çok tekrarlanan ilk ikisi, 38 tekrarla $(\% 61,29)$ Avrupa ve 20 tekrarla $(\% 32,26)$ Asya'dır. 
Tablo 5: Güvenli Bulunan Destinasyonlar

\begin{tabular}{|c|c|c|}
\hline Destinasyonlar & $\sum$ & $\%$ \\
\hline $\begin{array}{l}\text { Avrupa } \\
\text { (Belçika, Hollanda, Lüksemburg, Isviçre, Isveç, Norveç, } \\
\text { Danimarka/Kopenhag, Italya/Floransa, Çek Cumhuriyeti/Prag, } \\
\text { Makedonya, Almanya, Kuzey Irlanda, Ingiltere, Portekiz, } \\
\begin{array}{l}\text { Avusturya/Viyana, Yunanistan, Sırbistan, Belgrad, Bosna } \\
\text { Hersek/Saraybosna, Macaristan) }\end{array}\end{array}$ & 38 & 61,29 \\
\hline $\begin{array}{l}\text { Asya } \\
\text { (Güney Kore, Malezya, Nepal, Tayland, Hong Kong, Japonya, } \\
\text { Makau, Tayvan, Singapur } \\
\text { Güney Asya ülkelerinin bir bölümü, Türkiye'de Ege bölgesi, Eskişehir } \\
\text { ve Mardin) }\end{array}$ & 20 & 32,26 \\
\hline $\begin{array}{l}\text { Kuzey Amerika } \\
\text { (Chicago, Amerika ve Küba) }\end{array}$ & 3 & 4,84 \\
\hline Afrika & 1 & 1,61 \\
\hline$\sum$ & 62 & 100 \\
\hline
\end{tabular}

Katılımcıların ziyaret ettikleri ve güvenli buldukları destinasyonlardan en sık tekrar edenlerden bazıları; Avrupa'da Bosna Hersek, Portekiz, Danimarka, Norveç, İsviçre, Hollanda ve Belçika; Asya'da Tayland, Singapur, Japonya ve Güney Kore; Kuzey Amerika'da Küba, Amerika ve Chicago'dur.

Katılımcıların Tablo 5'te güvenli olduğunu belirttikleri destinasyonları güvenli bulma nedenlerine ilişkin içerik analizi bulguları Tablo 6'da sunulmaktadır. Katılımcıların güvenli bulma nedenlerine ilişkin en sık tekrarlanan ilk ifade, 26 tekrarla $(\% 49,06)$ destinasyonun gelişmişlik düzeyidir.

Tablo 6: Destinasyonların Güvenli Bulunma Nedenleri

\begin{tabular}{|l|c|c|}
\hline Nedenler & $\Sigma$ & $\%$ \\
\hline $\begin{array}{l}\text { Destinasyonun gelişmişlik düzeyi } \\
\text { (yaşam standartları, geniş yasaları ve hakları olması, gelişmiş ulaşım } \\
\text { ağı, sakin bir destinasyon oluşu vb. gibi unsurlar) }\end{array}$ & 26 & 49,06 \\
\hline $\begin{array}{l}\text { Misafirperver olması } \\
\text { (yerel halkın turiste yönelik olumlu tutumu) }\end{array}$ & 12 & 22,64 \\
\hline $\begin{array}{l}\text { Kadın olduğunu hissettirmemesi } \\
\text { (cinsiyete dayalı eylemlerin olmaması) }\end{array}$ & 10 & 18,87 \\
\hline $\begin{array}{l}\text { Diğer nedenler } \\
\text { (güvenliğin göreceli olduğunu düşünme, güvenliğin mekâna dayalı } \\
\text { olduğunu düşünmeme, olumlu deneyimler yaşanmaması vb. } \\
\text { nedenler) }\end{array}$ & 5 & 9,43 \\
\hline$\sum$ & $\mathbf{5 3}$ & $\mathbf{1 0 0}$ \\
\hline
\end{tabular}

Katılımcıların ziyaret ettikleri bu destinasyonları neden güvenli bulduklarına yönelik bazı ifadeler aşağıda sunulmuştur.

...Hong Kong, Tayland, Güney Kore, Japonya, Makau, Tayvan... Gece veya gündüz, sokaklarında istediğiniz gibi yürüyebilir, yalnız bir kadın olmanın rahatsızığını duymadan gezebilirsiniz. Insanlar yardımseverdir. Sizi tedirgin edecek davranışlarda bulunmazlar. (K8)

...Dünyanın herhangi bir yerine güvensiz demek hiç hoşuma gitmiyor. Seyahatlerimden sonra şunu fark ettim ki güvensiz denilen birçok nokta aslında gayet 
sorunsuz ve konforluydu. Dünyanın her yerinde kötü insanlar vardır. Seyahat ederken de kendinize göre birtakım önlemler alırsınız ancak bunu yerleşik düzende bulunduğunuz şehirde de yaparsınız zaten. (K19)

\subsection{Yalnız Seyahat Edilen ve Güvensiz Bulunan Destinasyonlara İlişkin Bulgular}

Katılımcıların yalnız seyahat ettikleri destinasyonlardan en güvensiz olduğunu belirttikleri destinasyonlara ilişkin içerik analizi bulguları Tablo 7'de sunulmaktadır. Katılımcılar tarafından en güvensiz bulunan destinasyonlardan en çok tekrarlanan ilk ikisi; 21 tekrarla $(\% 48,84)$ Avrupa ve 16 tekrarla $(\% 37,21)$ Asya'dır.

Tablo 7: Güvensiz Bulunan Destinasyonlar

\begin{tabular}{|c|c|c|}
\hline Destinasyonlar & $\Sigma$ & $\%$ \\
\hline $\begin{array}{l}\text { Avrupa } \\
\text { (Ispanya/ Barcelona, Italya/ Roma, Hollanda, Yunanistan, Almanya/Hamburg, } \\
\text { Bosna-Hersek/Saraybosna, Kosova/Prizren, Makedonya/Üsküp, } \\
\text { Portekiz/Lizbon, Belçika/Brüksel, Bulgaristan/Sofya, Fransa/Paris) }\end{array}$ & 21 & 48,84 \\
\hline $\begin{array}{l}\text { Asya } \\
\text { Malezya/Kuala Lumpur, Hindistan, Ürdün, Sri Lanka, Irak, Iran, Suriye, } \\
\text { Lübnan/Beyrut, diğer Arap ülkeleri, diğer Orta Asya ülkeleri ve Türkiye’de } \\
\text { Doğu Anadolu bölgesi ile Amasra, Konya, Sakarya, Kocaeli, Gebze şehirleri) }\end{array}$ & 16 & 37,21 \\
\hline $\begin{array}{l}\text { Kuzey Amerika } \\
\text { (New York ve Dominik Cumhuriyeti) }\end{array}$ & 2 & 4,65 \\
\hline $\begin{array}{l}\text { Güney Amerika } \\
\text { (Kolombiya ve Brezilya) }\end{array}$ & 2 & 4,65 \\
\hline $\begin{array}{l}\text { Afrika } \\
\text { (Güney Afrika'nın kırsalı ve Etiyopya) }\end{array}$ & 2 & 4,65 \\
\hline$\sum$ & 43 & 100 \\
\hline
\end{tabular}

Katılımcıların ziyaret ettikleri ve güvensiz buldukları destinasyonlardan en sık tekrar edenlerden bazıları; Avrupa'da Paris, İspanya ve İtalya; Asya'da özellikle Orta Doğu ülkeleri; Kuzey Amerika'da New York ve Dominik Cumhuriyeti; Güney Amerika'da Brezilya ve Kolombiya; Afrika'nın kırsalı ve Etiyopya'dır.

Katılımcıların Tablo 7'de yer alan destinasyonları güvensiz bulma nedenlerine ilişkin içerik analizi bulguları Tablo 8'de sunulmaktadır. Katılımcıların güvensiz bulma nedenlerine ilişkin en sık ifade edilen ilk iki neden, 17 tekrarla $(\% 36,17)$ destinasyondaki yetersiz güvenlik unsurları ve 11 tekrarla $(\% 23,40)$ yerel halkın olumsuz tutumudur.

Tablo 8: Destinasyonların Güvensiz Bulunma Nedenleri

\begin{tabular}{|l|c|c|}
\hline Nedenler & $\Sigma$ & $\%$ \\
\hline $\begin{array}{l}\text { Destinasyondaki yetersiz güvenlik unsurları } \\
\text { (sözlü taciz, fiziksel taciz, terör olayları, mafya, uyuşturucu satıcıları, } \\
\text { hırsızlık, dolandırıcılık vb. olayları) }\end{array}$ & 17 & 36,17 \\
\hline $\begin{array}{l}\text { Yerel halkın olumsuz tutumu } \\
\text { (tepkisiz/negatif/gergin/kaba vb. davranışlar, göz hapsinde olmak) }\end{array}$ & 11 & 23,40 \\
\hline Cinsiyetçi coğrafya olması ve kadına yönelik olumsuz bakış açısı & 8 & 17,02 \\
\hline $\begin{array}{l}\text { Büyükşehir olması } \\
\text { (kalabalık oluşu) }\end{array}$ & 6 & 12,77 \\
\hline Issız sokaklar ve sokakta yaşayanlar & 5 & 10,64 \\
\hline$\sum$ & 47 & 100 \\
\hline
\end{tabular}

Katılımcıların Tablo 7'de yer alan destinasyonları neden güvensiz bulduklarına yönelik bazı ifadeler aşağıda sunulmuştur. 
... Ittalya'nın çoğu yerinin problemli olduğunu düşünüyorum. Gerek şehir içinde gerek tren istasyonlarında sürekli bir şeyleriniz çalınmasın diye tetikte olmak zorundasınız. Gece bulunduğum mekanlarda sayısız kez fiziksel tacize uğradım. Yolculuk esnasında veya tren beklerken yalnız kalmak için ekstra çaba sarf etmek durumunda kalıyordum; mutlaka birileri gelip konuşmak istiyor çünkü. (K12)

... Brüksel: Katılmış olduğum keşif turunda turun başından beri sanki bizden biriymiş gibi aramızda dolaşan kişi yan kesicilik yapmaya kalktı... Paris: Aynı şekilde çok fazla göçmen var... Roma: Benzer şekilde bir şeyler satmaya çalışan satıcılar aşırı Israrcı davranabiliyor. Ara sokaklarda yolunuzu kesip taciz etmeye kalkan kişiler de var. (K23)

... Ortadoğu savaş burada belirleyici faktör. Irak, Iran, Suriye, Beyrut. Insan profili ve coğrafya çok etkili, gergin - agresif - mutsuz insanlar sana zarar verebilir diye düşünüyorsun, bu beni geriyordu ve kadına bakışları seks objesi. Büyük kesim bu şekilde, bu yüzden adımlar hep hızlıydı. (K2)

\subsection{Yalnız Seyahat Etmek İstenilen Ancak Gidilmeyen Destinasyonlara İlişkin Görüşler}

Katılımcıların yalnız seyahat etmek isteyip gitmedikleri destinasyonlara ilişkin içerik analizi bulguları Tablo 9'da sunulmaktadır. Katılımcıların gitmedikleri destinasyon olarak en çok tekrarlananlardan ilki, 19 tekrarla $(\% 57,58)$ Asya'dır.

\section{Tablo 9: Gidilmeyen Destinasyonlar}

\begin{tabular}{|c|c|c|}
\hline Destinasyonlar & $\Sigma$ & $\%$ \\
\hline $\begin{array}{l}\text { Asya } \\
\text { (Ürdün, Afganistan, Suriye/Şam, Iran, Irak, Suudi Arabistan, Pakistan, } \\
\text { Moğolistan, Kuzey Kore, Chin, Japonya ve diğer Arap ülkeleri ve diğer } \\
\text { Orta Doğu ülkelerinin belirli yerleri) }\end{array}$ & 19 & 57,58 \\
\hline $\begin{array}{l}\text { Afrika } \\
\text { (Doğu Afrika, Libya, Fas'ın bazı bölgeleri, Namibya ve Mısır) }\end{array}$ & 5 & 15,15 \\
\hline $\begin{array}{l}\text { Avrupa } \\
\text { (Ispanya/Barselona ve İzlanda) }\end{array}$ & 4 & 12,12 \\
\hline $\begin{array}{l}\text { Kuzey Amerika } \\
\text { (Orta Amerika'da El Salvador ve Honduras) }\end{array}$ & 3 & 9,09 \\
\hline $\begin{array}{l}\text { Okyanusya } \\
\text { (Yeni Zelanda ve Avustralya) }\end{array}$ & 2 & 6,06 \\
\hline$\Sigma$ & 33 & 100 \\
\hline
\end{tabular}

Tablo 9'da yer alan ve katılımcıların henüz seyahat etmedikleri destinasyonlara neden gitmediklerine yönelik en sık ifade edilen nedenler, 14 tekrarla $(\% 45,16)$ güvenlik sorunları ve 12 tekrarla $(\% 38,71)$ ekonomik kısıtlar ve 5 tekrarla $(\% 16,13)$ diğer nedenlerdir. Katılımcıların yalnız seyahat etmek istedikleri ancak henüz seyahat etmedikleri bu destinasyonlara neden gitmediklerine yönelik bazı ifadeler aşağıda sunulmaktadır.

...Pakistan'a gitmeyi çok istedim fakat tek başıma gidersem çok problem yaşayacağımı söylediler. (K26)

... Barselona. Gasp ve kapkaççılıkla ilgili hem çok şey okudum hem de seyahat etmiş kişilerden çok fazla talihsiz olay dinledim. Sokakta dolaşırken yine bir nebze önlemimi alabilir ve kendimi koruyabilirim belki ancak hotel, hostel gibi konaklama 
tesislerinde dahi bu tip suçların profesyonel hale gelmiş kişilerce işlendiğini öğrenmek böyle bir riski alıp almamak konusunda tereddüde düşürdü. (K23)

\subsection{Etkinliklere Katılıma İlişkin Bulgular}

Katılımcıların yalnız seyahatlerinde katıldıkları etkinliklere ilişkin içerik analizi bulguları Tablo 10'da sunulmaktadır. Katıldıkları etkinliklere ilişkin en çok tekrarlanan, 22 tekrarla $(\% 59,46)$ yerel kültürü tanımaya yönelik etkinliklerdir.

\section{Tablo 10:Kadınların Yalnızken Katıldıkları Etkinlikler}

\begin{tabular}{|l|c|c|}
\hline Etkinlikler & $\Sigma$ & $\%$ \\
\hline $\begin{array}{l}\text { Yerel külttürü tanımaya yönelik etkinlikler } \\
\text { (tarihi yerler, yerel kültüre ait mekânlar ve müze ziyaretleri, şehir, sokak } \\
\text { turları/gezileri, kültürel ve sanatsal etkinlikler, yerel mutfağı, kültürünü } \\
\text { ögrrenme v.b.) }\end{array}$ & 22 & 59,46 \\
\hline Doğa ile iç içe olma & 10 & 27,03 \\
\hline $\begin{array}{l}\text { Yeni arkadaşlarla yapılan programlara katılma } \\
\text { (yerel halk ile sosyal ilişki kurma) }\end{array}$ & 4 & 10,81 \\
\hline Adrenalin içeren etkinliklere katılma & 1 & 2,70 \\
\hline$\Sigma$ & $\mathbf{3 7}$ & $\mathbf{1 0 0}$ \\
\hline
\end{tabular}

Katılımcıların yalnız seyahatlerinde katılmadıkları etkinliklere ilişkin içerik analizi bulguları Tablo 11'de sunulmaktadır. Katılmadıkları etkinliklere ilişkin en çok tekrarlanan, 5 tekrarla $(\% 35,71)$ grup olarak yapılan etkinliklerdir.

\section{Tablo 11:Kadınların Yalnızken Katılmadıkları Etkinlikler}

\begin{tabular}{|c|c|c|}
\hline Etkinlikler & $\Sigma$ & $\%$ \\
\hline Grup olarak yapılan etkinlikler & 5 & 35,71 \\
\hline $\begin{array}{l}\text { Aykırılık içeren etkinlikler } \\
\text { (seksle ilgili, şiddet içerikli, alkol ya da uyuşturucunun yoğun kullanıldı̆̆ı } \\
\text { eğlenceler) }\end{array}$ & 3 & 21,43 \\
\hline Geceleri yapılan etkinlikler & 2 & 14,29 \\
\hline Adrenalin içeren etkinlikler & 2 & 14,29 \\
\hline Masraflı etkinlikler & 1 & 7,14 \\
\hline Yeni tanışılan insanların davet ettiği etkinlikler & 1 & 7,14 \\
\hline$\Sigma$ & 14 & 100 \\
\hline
\end{tabular}

Tablo 11'de yer alan etkinliklere katılımcıların katılmama nedenlerine yönelik içerik analizi bulguları, 9 tekrarla $(\% 50,00)$ yalnız olmaları, 5 tekrarla $(\% 27,78)$ etkinliğin riskli olması, 3 tekrarla $(\% 16,67)$ bir gruba dâhil olmak istememe ve 1 tekrarla $(5,56)$ etkinliğin masraflı olması şeklindedir.

\subsection{Kadınların Yalnız Seyahatlerinde Cesaret Arttıran ve Cesaret Kıran Deneyimlerine İlişkin Bulgular}

Katılımcıların yalnız seyahat ederken cesaretlerini arttıran deneyimlere ilişkin içerik analizi bulguları Tablo 12 'de sunulmaktadır. Cesaret veren deneyimlerden en çok tekrarlananlardan ilki, 16 tekrarla $(\% 38,10)$ kişisel gelişimdir. 
Tablo 12: Cesaretlerini Arttıran Deneyimler

\begin{tabular}{|l|c|c|}
\hline Deneyimler & $\Sigma$ & $\%$ \\
\hline Kişisel gelişim & 16 & 38,10 \\
\hline Yeni dostluklar edinmek & 8 & 19,05 \\
\hline Yerel halkın desteği & 8 & 19,05 \\
\hline Diğer gezginler ve arkadaşların motivasyonu & 5 & 11,90 \\
\hline Özgür olmak & 3 & 7,14 \\
\hline Prestij kazanmak & 2 & 4,76 \\
\hline$\Sigma$ & $\mathbf{4 2}$ & $\mathbf{1 0 0}$ \\
\hline
\end{tabular}

Katılımcıların yalnız seyahat ederken cesaretlerini kıran deneyimlere ilişkin içerik analizi bulguları Tablo 13'te sunulmaktadır. Cesaret kıran deneyimlerden en çok tekrarlananlardan ilki, 7 tekrarla $(\% 53,85)$ güvenlik sorunları/güvende hissetmemedir.

Tablo 13: Cesaretlerini Kıran Deneyimler

\begin{tabular}{|l|l|l|}
\hline Deneyimler & $\Sigma$ & $\%$ \\
\hline $\begin{array}{l}\text { Güvenlik sorunları/güvende hissetmeme } \\
\text { (insanların olumsuz tutumları/sözleri/bakışları, yerel } \\
\text { erkeklerin olumsuz tavrı, taciz, hırsızlık, dolandırıcılık ve } \\
\text { değerli eşyalara yalnız olarak sahip çıkmaya çalışma) }\end{array}$ & 7 & 53,85 \\
\hline $\begin{array}{l}\text { Yaşanan aksaklıklar } \\
\text { (ulaşım sorunu, araç bulamama vs.) }\end{array}$ & 3 & 23,08 \\
\hline Etkinliklerde yalnız olma & 2 & 15,38 \\
\hline Geceleri dışarıya yalnız çıkamama & 1 & 7,69 \\
\hline$\Sigma$ & $\mathbf{1 3}$ & $\mathbf{1 0 0}$ \\
\hline
\end{tabular}

Katılımcıların yalnız seyahatlerinde karşılaştıkları durumlardan dolayı cesaret veren ve cesaretlerini kıran deneyimlere ilişkin bazı ifadeler aşağıda sunulmuştur.

... Cesaretimi artıran, yalnız seyahatlerde hem yolda tanıştığım diğer seyahat edenler, hem de geçtiğim coğrafyalarda tanıştığım lokal insanların tutumunun, yaklaşımının beni motive ettiğini söyleyebilirim. (K9)

... Cesaretimi arttıran çok fazla olay oldu. Her şeyden önce yeni insanlarla tanışmak yalnızken çok daha kolay ve bu da bana oldukça keyif veriyor. Cesaretimi kıran ise kötü söz ya da tacizkâr bakışlar oldu diyebilir miyim bilmiyorum çünkü bunlardan her ne kadar rahatsız olsam da yine de bir daha yalnız seyahat etmeyeceğim hissini bana yaşatmadılar. (K31)

\subsection{Kadınların Yalnız Seyahatlerinde Olumlu ve Olumsuz Seyahat Deneyimlerine İlişkin Bulgular}

Katılımcıların yaşadığı en olumlu deneyimlere ilişkin içerik analizi bulguları Tablo 14'te sunulmaktadır. En çok tekrarlanan en olumlu deneyimlerden ilki, 13 tekrarla $(\% 37,14)$ yerel halkın desteği ile karşılaşmadır. 
Tablo 14: En Olumlu Seyahat Deneyimleri

\begin{tabular}{|l|l|l|}
\hline Olumlu Deneyimler & $\Sigma$ & $\%$ \\
\hline Yerel halkın desteği ile karşılaşma & 13 & 37,14 \\
\hline Kişisel gelişim ve kendini keşfetme fırsatı bulmak & 10 & 28,57 \\
\hline Edinilen dostluklar & 8 & 22,86 \\
\hline Prestij kazanmak & 2 & 5,71 \\
\hline Kadınların birbirine karşı bağlıı̆ı ve desteği & 2 & 5,71 \\
\hline$\Sigma$ & $\mathbf{3 5}$ & $\mathbf{1 0 0}$ \\
\hline
\end{tabular}

Katılımcıların en olumlu olarak nitelendirdikleri deneyimlere yönelik bazı ifadeler aşağıda sunulmuştur.

...Dünyanın öbür ucunda ortak hiçbir dili konuşamadığımız hiç anlaşamadığımız insanlarla Kamboçya'da on gün boyunca yaşamak benim için mükemmel bir deneyimdi. (K26)

...Gezilerde kendimi çok daha iyi tanıma fırsatım oldu. Korkularımı, sevdiğim ve sevmediğim şeyleri çok daha net anlamama yardımcı oldu. (K24)

Katılımcıların yaşadığı en olumsuz deneyimlere ilişkin içerik analizi bulguları Tablo 15'de sunulmaktadır. En çok tekrarlanan en olumsuz deneyimlerden ilki, 9 tekrarla $(\% 39,13)$ güvenlik sorunları/ güvende hissetmemedir.

\section{Tablo 15: En Olumsuz Seyahat Deneyimleri}

\begin{tabular}{|l|c|c|}
\hline Olumsuz Deneyimler & $\Sigma$ & $\%$ \\
\hline $\begin{array}{l}\text { Güvenlik sorunları/güvende hissetmeme } \\
\text { (hırsızlık, i̧ çatışma(kaos), pansiyonlardaki/hostellerdeki } \\
\text { güvensizlik hissi, seyahat planını aksatan dolandırııılık) }\end{array}$ & 9 & 39,13 \\
\hline $\begin{array}{l}\text { Yerel halkın göz hapsinde olma/istenmeyen } \\
\text { davranışlar }\end{array}$ & 8 & 34,78 \\
\hline $\begin{array}{l}\text { Taciz } \\
\text { (fiziksel-psikolojik) }\end{array}$ & 6 & 26,09 \\
\hline$\Sigma$ & $\mathbf{2 3}$ & $\mathbf{1 0 0}$ \\
\hline
\end{tabular}

Katılımcıların en olumsuz olarak nitelendirdikleri deneyimlere yönelik bazı ifadeler aşağıda sunulmuştur.

...Olumsuz deneyimler de genelde karşı cinsin tereddütte bırakan söz ve davranışları olarak karşıma çıkıyor.(K8)

...Malezya'da tüm elektronik eşyalarım çalındı. (K6)

\subsection{Yalnız Seyahat Etmenin Avantaj ve Dezavantajlarına İlişkin Bulgular}

Katılımcıların belirtmiş olduğu yalnız seyahat etmenin avantajlarına ilişkin içerik analizi bulguları Tablo 16 'da sunulmaktadır. Katılımcılar tarafından avantaj olarak en çok tekrarlananlardan ilki, 27 tekrarla $(\% 38,03)$ özgür olmadır. 
Tablo 16: Yalnız Seyahat Etmenin Avantajları

\begin{tabular}{|l|c|c|}
\hline Avantajlar & $\Sigma$ & $\%$ \\
\hline $\begin{array}{l}\text { Özgür olma } \\
\text { (istediğini yapıp yapmama/bireysel karar alma) }\end{array}$ & 27 & 38,03 \\
\hline Kendini keşfetme fırsatı bulma & 16 & 22,54 \\
\hline Kişisel gelişim/özgüvenin artması & 11 & 15,49 \\
\hline Sosyalleşme/daha çok insan tanıma & 9 & 12,68 \\
\hline Seyahati daha derin deneyimleme fırsatı & 7 & 9,86 \\
\hline Masrafların daha az olması & 1 & 1,41 \\
\hline$\Sigma$ & $\mathbf{7 1}$ & $\mathbf{1 0 0}$ \\
\hline
\end{tabular}

Katılımcıların yalnız seyahat ederken avantaj olarak gördükleri durumlara yönelik ifadelerinden bazıları aşağıda sunulmuştur.

...Yalnız seyahat etmek müthiş bir bağımsızlık veriyor. (K6)

...Insan kendini daha iyi tanıyor, her gezi başka bir güzellik katıyor ruhuma ve kuş gibi özgür hissediyorum kendimi. (K11)

Katılımcıların belirtmiş olduğu yalnız seyahat etmenin dezavantajlarına ilişkin içerik analizi bulguları Tablo 17 'de sunulmaktadır. Dezavantaj olarak en çok tekrarlananlardan ilk ikisi, 15 tekrarla $(\% 26,32)$ anlık duyguları paylaşamamak ve 14 tekrarla $(\% 24,56)$ intiyaç duyulduğunda kimsenin olmamasıdır.

Tablo 17: Yalnız Seyahat Etmenin Dezavantajları

\begin{tabular}{|l|c|c|}
\hline Dezavantajlar & $\sum$ & $\%$ \\
\hline Anlık duyguları paylaşamama & 15 & 26,32 \\
\hline $\begin{array}{l}\text { Ihtiyaç duyulduğunda kimsenin olmaması } \\
\text { (hastalıkta yalnız olmak gibi) }\end{array}$ & 14 & 24,56 \\
\hline $\begin{array}{l}\text { Maliyetlerin artması } \\
\text { (çift kişilik rezervasyon alınması, kalabalık hostel } \\
\text { odalarında kalmak zorunda olmak) }\end{array}$ & 9 & 15,79 \\
\hline Fotoğraf ve video çekecek kimsenin olmaması & 8 & 14,04 \\
\hline $\begin{array}{l}\text { Grupla yapılan etkinliklere katılamamak } \\
\text { (gece dışarıya çıkamamak) }\end{array}$ & 6 & 10,53 \\
\hline Cinsiyete dayalı olumsuz davranışlarla karşılaşmak & 4 & 7,02 \\
\hline Yalnız yürümek & 1 & 1,75 \\
\hline$\sum$ & $\mathbf{5 7}$ & $\mathbf{1 0 0}$ \\
\hline
\end{tabular}

Katılımcıların yalnız seyahat ederken dezavantaj olarak gördükleri durumlara yönelik ifadelerinden bazıları aşağıda sunulmuştur.

...Fotoğraf ve video çekecek kimse yok asla şıkır şıkır giyinip çıkamıyorum hep taşınıyor gibiyim. (K2)

... \%100 güvenebileceğiniz birinin yanınızda olmaması, her şeye şüpheyle yaklaşmak zorunda kalmak, konaklama ve gezi faaliyetlerinde fiyat bölüşememek. (K32) 


\subsection{Olumsuz Durumlarla Başa Çıkma Yöntemlerine İlişkin Bulgular}

Katılımcıların yalnızken karşılaştıkları olumsuz durumlarla başa çıkma yöntemlerine ilişkin içerik analizi bulguları Tablo 18'de sunulmaktadır. En çok tekrarlanan başa çıkma yöntemlerinden ilki, 21 tekrarla $(\% 43,75)$ sakin kalmadır.

Tablo 18: Olumsuzluklarla Başa Çıkma Yöntemleri

\begin{tabular}{|l|l|l|}
\hline İadeler & $\Sigma$ & $\%$ \\
\hline Sakin kalma & 21 & 43,75 \\
\hline Çevredeki insanlardan yardım alma & 9 & 18,75 \\
\hline $\begin{array}{l}\text { Riskli ortamdan uzaklaşma } \\
\text { (rota değiştirerek, kalabalığa karışarak, riskten kaçınarak) }\end{array}$ & 9 & 18,75 \\
\hline $\begin{array}{l}\text { Tedbirli olma } \\
\text { (hastalanmaya karşı ilk yardım çantası alma, parayı farklı } \\
\text { yerlere saklama, yerel kültüre ait temel kelimeleri/dili } \\
\text { öğrenme vb. tedbirler alma) }\end{array}$ & 8 & 16,67 \\
\hline Yalnız değilmiş gibi davranma & 1 & 2,08 \\
\hline$\sum$ & $\mathbf{4 8}$ & $\mathbf{1 0 0}$ \\
\hline
\end{tabular}

Katılımcıların olumsuzluklarla başa çıkmada kullandıkları yöntemlere ilişkin bazı ifadeler aşağıda sunulmuştur.

...Mesela paramın bir kısmını çantamın dibinde tutuyorum bir kısmını boynumdan bağlı küçük çantamda saklıyorum. Eğer bir mekânda, sokakta kötü hissedersem uzaklaşıyorum, daha kalabalık yerlere gidiyorum.(K4)

...Panik yapmamaya, eğer korkmuşsam bunu dışarıya belli etmemeye çalışıyorum. Çaresiz görünen bir kadına yarardan çok zararı dokunanlar olabilir; sorunumu herkesle paylaşmamaya özen gösteriyorum. Birilerinden destek almam gerektiği noktada daha güvenilir tiplerden seçmeye çalışıyorum. (K12)

... Aslında acı bir yöntem bu... Benim başa çıkma yöntemim beni rahatsız eden kişilere yalnız olmadığıma ilişkin şeyler söylemek oluyor çünkü. Eşim otelde beni bekliyor, arkadaşım beni arabayla buradan alacak vb. (K31)

\subsection{Kadınların Yalnız Seyahat Etme Kararlarına Yönelik Çevreden Gelen Tepkilere İlişkin Bulgular}

Katılımcıların ilk kez yalnız seyahate çıkma girişimlerinde aile, arkadaş, akraba vb. çevrelerinden aldıkları geri dönüşlere ilişkin içerik analizi bulgularında; 20 kişi "olumsuz", 8 kişi "olumlu", 5 kişi ise "ne olumlu ne olumsuz" tepkilerle karşılaştıklarını ifade etmiştir. Katılımcıların daha sonraki yalnız seyahat etme kararlarına yönelik tepkilere ilişkin içerik analizi bulgularında; 29 kişi "olumlu", 2 kişi "olumsuz" ve 2 kişi de "ne olumlu ne olumsuz" tepkiler aldığını ifade etmiştir. Katılımcıların çevrelerinden gelen tepkilere ilişkin bazı ifadeler aşağıda sunulmuştur.

...Dünya turuna çıkmaya karar verdiğimde, uzaktan yakından tanıdığım tanımadığım insanlardan birçok farklı tepkiyle karşılaştım. Bazıları hayranlıkla ve cesaretlendirici dileklerle karşılık verirken bazıları da milyonlarca negatif cümle sarf etti. Şimdi negatifler çok uzağımda, çünkü hepsi birer birer kopup gitti. Ailem ise alıştı hala her Türkiye'ye uğradığımda hadi bir gez gel de cümlesi sarf ediliyor ama onun dışında negatif bir tepkileri yok. (K3) 
...illk söylediğimde neden böyle bir şey yapmak istediğimi anlamlandıramadılar ve güvenli bulmadıklarını, bu fikirden vazgeçmem gerektiğini ifade ettiler. Ancak şimdilerde gayet destekleyici tepkiler alıyorum. Benim yerime heyecanlanmakla kalmayıp eşlik etmek istiyorlar.(K19)

\subsection{Yalnız Seyahatlere Yönelik Gelecek Planına İlişkin Bulgular}

Katılımcıların tek başına/yalnız olarak seyahat etmeye devam edip etmeyeceklerine ilişkin içerik analizi bulgularında; 31 kişi 'evet', 1 kişi 'hayır', 1 kişi de geleceğe yönelik planının olmadığını ifade etmiştir.

\subsection{Yalnız Seyahat Edecek Kadınlara Yönelik Tavsiye ve Önerilere İlişkin Bulgular}

Katılımcıların yalnız seyahat etmeyi düşünen kadınlara yönelik tavsiye ve önerilerine ilişkin içerik analizi bulguları Tablo 19'da sunulmaktadır. Yalnız seyahat etmeyi düşünen kadınlara yönelik en sık ifade edilen tavsiye ve önerilerden ilk ikisi, 23 tekrarla $(\% 42,59)$ cesur olsunlar ve 9 tekrarla $(\% 16,67)$ tedbiri elden bırakmasınlar şeklindedir.

Tablo 19: Yalnız Seyahat Edecek Kadınlara Tavsiye ve Öneriler

\begin{tabular}{|l|c|c|}
\hline İ́adeler & $\Sigma$ & $\%$ \\
\hline Cesur olsunlar & 23 & 42,59 \\
\hline $\begin{array}{l}\text { Tedbiri elden bırakmasınlar } \\
\text { (parayı birkaç farklı yere saklamak rotalarını yakınlarıyla } \\
\text { paylaşmak, güvenliğe yönelik her türlü tedbiri almak vb.) }\end{array}$ & 9 & 16,67 \\
\hline $\begin{array}{l}\text { Ön araştırma yapsınlar } \\
\text { (diğer gezginlerin yorumları, destinasyon koşullarını araştırma vb. ) }\end{array}$ & 8 & 14,81 \\
\hline Kadına yönelik olumsuz tutumları kabul etmesinler & 5 & 9,26 \\
\hline Kendi deneyimlerini yaşasınlarl kendilerini keşfetsinler & 4 & 7,41 \\
\hline İletişime açı olsunlar & 3 & 5,56 \\
\hline Gezginlerin konakladığı hostel gibi yerleri tercih etsinler & 1 & 1,85 \\
\hline Ara sıra grup gezilerine katılsınlar & 1 & 1,85 \\
\hline$\sum$ & $\mathbf{5 4}$ & $\mathbf{1 0 0}$ \\
\hline
\end{tabular}

Katılımcıların yalnız seyahat etmek isteyen kadınlara yönelik tavsiye ve önerilerini belirttikleri ifadelerden bazıları aşağıda sunulmuştur.

...Korkmasınlar. Toplumun onlara dayattıklarını kabul etmesinler. Çünkü her şeyi yapabilecek güçteler. Şöyle bir söz vardır. "Korku kapıyı çaldı. Cesaret kapıyı açtı. Korku kapıda yoktu." Korkunun onlara öğretildiği ve kendi zihinlerinde yarattıkları bir olgu olduğunun farkına varsınlar. Tabi ki de güvenliklerini de sağlayarak seyahat etsinler. Dünya bize anlatılı̆̆ı gibi kötü bir yer değil.(K6)

...Korkmayın ve hayallerinizin peşinden gidin. Emin olun dünyada güzel şeylerde oluyor. (K16)

\section{Sonuç}

Yalnız seyahat eden kadınlara yönelik yapılmış olan çalışmalar, yalnız seyahatlerin sosyal yapılardaki ve yaşam tarzlarındaki değişimlerden kaynaklandığını ve en hızlı büyüyen turizm pazar bölümleri arasında olduğunu göstermektedir (Yang ve diğ., 2018; Kaba ve Emekli, 2018; Valaja, 2018:8; Tilley ve Houston, 2016; Khan, 2011; 
McNamara ve Prideaux, 2010; Wilson ve Little 2008; Jordan ve Gibson, 2005; Wilson ve Little 2005; Mehmetoğlu ve diğ., 2001; Bond, 1997). Bu araştırmada da yalnız seyahat eden kadınların seyahat deneyimleri ele alınmıştır. Bu bağlamda araştırma da yalnız seyahat eden kadınların; neden yalnız seyahat ettikleri, destinasyon seçim süreçleri, güvenli ve güvensiz buldukları destinasyonlar, katıldıkları ve katılmadıkları etkinlikler, cesaretlerini artıran ve kıran nedenler, yaşadıkları olumlu ve olumsuz deneyimler, yalnız seyahatin avantajları ve dezavantajları, olumsuzluklarla başa çıkma yolları, çevreden gelen tepkiler, seyahatle ilişkili gelecek planları, ziyaret edilen destinasyonlar, yalnız seyahat edecek kadınlara tavsiye ve önerilerinin neler olabileceğini belirlemek amaçlanmıştır.

Araştırma bulgularından yalnız seyahat eden kadınların, yüksek eğitimli oldukları, kendilerini ağırlıklı olarak orta gelirli olarak gördükleri ve büyük çoğunluğu bekâr olsa da evli kadınların da yalnız seyahat edebildikleri sonucuna ulaşıımıştır.

Araştırmanın bulgularında kadınların yalnız seyahat etme nedenlerinden; yalnız olma isteği öncelikli neden olarak görülürken, seyahat arkadaşının olmaması (eş/arkadaş bulamama) ve diğer nedenlerinde yalnız seyahat etme kararında etkili olduğu sonucuna ulaşılmıştır. Bu sonuç, Mehmetoğlu ve diğ. (2001); araştırmasındaki yalnız seyahat etme gerekçelerini destekler niteliktedir.

Kadınların yalnız seyahat etmedeki temel amaçlarının; özgür/bağımsız olmak (özerklik), kendini keşfetmek ve yenilenmek (içsel yolculuk yapma), kendini güçlendirmek ve kendi alanlarını genişletmek (doğayı, kültürleri, yerleri yalnız keşfederek) ve yeni insanlarla tanışma arzusu olduğu sonucuna ulaşılmıştır. Bu sonuç daha önce yapılmış araştırmaların (Pekiner, 2019:47-48; Pereira ve Silva, 2018; McNamara ve Prideaux, 2010; Laing ve Crouch, 2009) bulguları ile büyük oranda örtüşmektedir.

Araştırma bulgularında destinasyon seçim sürecinde; destinasyonun güvenlik koşullarının dikkat edilen en önemli faktör olması, Bond'un (1997) araştırmasında belirttiği güvenliğin kadınlar için temel endişe kaynağı olduğu ve Kaba ve Emekli'nin (2018) destinasyon seçiminde en etkili unsurun güvenlik olduğu bulgusunu desteklemektedir. Destinasyonun popülerliğinin ise, seçim sürecinde dikkat edilen en önemli ikinci faktör olduğu görülmüştür. Diğer yandan destinasyon seçim sürecinde dikkat edilen; ekonomik uygunluk, mesafe/erişilebilirlik ve destinasyonun iklim koşulları/mevsimi katılımcıların önem verdiği faktörlerdendir.

Araştırma bulgularında, güvenli ve güvensiz destinasyonlarla ilgili sıralamanın benzer olduğu görülmüştür. Katılımcıların güvenli ve güvensiz olarak nitelendirdikleri destinasyonlara yönelik tutumlarının; güvenlik algısındaki farklılıktan, güvenlik düzeyinin kişiden kişiye değişmesinden, destinasyonlardaki mevcut güvenlik unsurlarından ve yaşanan olumlu ya da olumsuz deneyimlerden kaynaklandığını söylemek mümkündür.

Elde edilen bulgular sonucunda, yalnız seyahat eden Türk kadınlarının en güvensiz bulduğu destinasyonlar; Avrupa'da özellikle İspanya/Barselona, İtalya/ Roma ve Fransa/Paris; Asya'da ise Fas, Libya, Mısır, Irak, İran, Suudi Arabistan, Ürdün ve diğer Arap ülkeleridir. Güvensiz bulunan Avrupa ülkelerinin en çok turist çeken turizm ülkeleri olması araştırmanın ilginç sonuçlarından birisi olarak değerlendirilebilir.

Wilson ve Little, (2008) yalnız seyahat eden kadınların belirli destinasyonları yüksek-riskli olarak algıladıklarını belirtmiştir. Kaba ve Emekli'nin 2018 yılında yayınlanan araştırmasında Pakistan, Hindistan, Ortadoğu, Uzakdoğu ve Kuzey Afrika 
gidilmek istenmeyen ya da gitmekte tereddüt edilen yerler olarak çıkmıştır. Bu araştırmada da, bazı kadınların yalnız seyahat etmek istedikleri ancak henüz gitmedikleri destinasyonların Ürdün, Afganistan, Suriye/Şam, İran, Irak, Suudi Arabistan, Pakistan, Moğolistan, Kuzey Kore, Çin, Japonya ve diğer Arap ülkeleri ve diğer Orta Doğu ülkelerinin belirli yerleri, Doğu Afrika, Libya, Fas'ın bazı bölgeleri, Namibya ve Mısır, İspanya/Barselona ve İzlanda, Orta Amerika ülkelerinden El Salvador ve Honduras, Yeni Zelanda ve Avustralya olduğu ve gitmeme sebeplerinin de destinasyonlardaki güvenlik sorunları, destinasyonun pahalılığı, bütçe sorunu ve diğer nedenler (destinasyona yönelik ön yargı ve kişisel nedenler) olduğu sonucuna ulaşılmıştır.

Araştırmalar genel olarak yalnız seyahat eden kadınların bazı mekânları ve etkinlikleri riskli olarak algıladıklarından söz etmektedir (Yang ve diğ., 2018; Wilson ve Little, 2008). Katılımcılar; grup olarak yapılan, aykırılık içeren (seksle ilgili, şiddet içerikli, alkol ya da uyuşturucunun yoğun kullanıldığı eğlenceler ), gece yapılan, adrenalin içeren, masraflı olan ve yeni tanışılan insanların davet ettiği etkinliklere katılımda tereddüt etmektedirler. Bu etkinliklere katılmama nedenleri ise; yalnız olmaları, etkinliklerin riskli olması, bir gruba dâhil olmak istememe ve etkinliklerin masraflı olmasıdır. Bu bulgulardan yola çıkarak yalnız seyahat etmenin bile zor kabul gördüğü günümüzde, yalnız seyahat eden kadınların daha da sıra dışı veya marjinal sayılabilecek faaliyetlerden kaçınmaları doğal sayılabilir.

Genel olarak bulgular değerlendirildiğinde yalnız seyahat eden kadınların seyahatleri sırasında yalnızlığın dezavantajını özellikle gece dışarıya çıkma ve gece etkinliklerine katılma konusunda yaşadıkları (gece etkinliklerini riskli buldukları için etkinliğe katılmadıkları) görülmektedir. Kadınların aldıkları bu tedbire rağmen taciz, hırsızlık, dolandırıcılık gibi birçok olumsuzlukla karşılaştıkları araştırmanın ortaya koyduğu gerçekliklerdir. Yalnız seyahat eden kadınlar seyahatlerde yaşanan olumsuzluklara karşın yalnız seyahat etmenin en önemli getirilerinin özgürlük duygusunu yaşama, kişisel olarak gelişim, özgüven duygusunun gelişmesi ve sosyalleşme olduğunu söylemektedir. Bu anlamıyla da yalnız seyahat etmenin kadınların gelişimine ve toplumdaki kadın erkek eşitsizliğinin azaltımasına katkıda bulunacağı söylenebilir.

Katılımcılar ilk kez yalnız seyahat etmeye karar verdiklerinde aile, arkadaş, akraba vb. çevrelerinden aldıkları geri dönüşlerin olumsuz olduğunu belirtmişlerdir. Olumsuz tepkiler, yalnız bir kadın olarak seyahat etmenin güvenli olmayacağına dair düşüncelerden kaynaklanmaktadır. Ancak olumsuz geri dönüşler zaman içerisinde yalnız seyahat sayısının da artmasıyla olumlu yönde değişime uğramıştır. Ayrıca katılımcıların gelecek seyahat planlarının, yalnız seyahatlere devam etme yönünde olacağı da ulaşılan bir diğer sonuçtur. Bu bulgulardan hareketle yalnız seyahat eden kadın sayısının artmaya devam edeceği söylenebilir.

Araştırma sonuçlarından elde edilen bilgiler doğrultusunda; yalnız seyahat eden kadınların yalnız olma isteğiyle seyahatlere başladıklarını, yakın çevrelerinin kadın olarak yalnız seyahatlere karşı olumsuz tutum sergilediklerini ancak zamanla bu tutumların olumlu yönde değiştiğini, seyahatlerinde olumsuz durumlarla karşılaşsalar bile bu durumlarla başa çıkabilmek için kendi stratejilerini oluşturduklarını, yalnız seyahatlerin bazı olumsuzlukları ve dezavantajlarına rağmen çok olumlu deneyimler kazandırdığını, yalnız seyahat etmekten memnun olduklarını ve yalnız seyahat etmenin risklerinin farkında olup tedbirli davranarak henüz gitmedikleri destinasyonlara yalnız seyahat etmeye devam edeceklerini söylemek mümkündür. 
Cinsiyete dayalı kısıtlar göz önüne alındığında, güvenlik konuları ile ilgili önlemler alınması, kadınlara yönelik olumsuz girişimlere yaptırım uygulanması, özgür ve daha eşit bir platform yaratılmasının yeni bir turizm pazarını oluşturan kadınların, turizm faaliyetlerine katılımına olumlu yansıyacağı düşünülmektedir. Hem sektör yöneticilerine hem de politik güçlere bu konuda büyük sorumluluk düşmektedir. Ayrıca güç arayışlarının yalnız seyahat eden kadınları güçlendirme düzeyi ile ilgili çalışmaların yapılması da araştırmaya değer bir konudur.

Her araştırmanın olduğu gibi bu araştırmanında sınırılıkları mevcuttur. Özellikle bu araştırma verilerinin yüz yüze görüşmeyle değil de internet aracılığı ile elde edilmiş olması verilerinde sınırlı olmasına neden olmuştur. Bir başka önemli kısıt ise araştırmanın yalnızca yalnız seyahat eden Türk kadınlarıyla yapılmış olmasıdır. Bu kısıtlara rağmen bu araştırmanın konu ile sınırlı sayıdaki araştırmanın artmasına ve dolayısıyla da literatüre katkı sağlayacağı düşünülmektedir. Bu konuda çalışma yapacak araştırmacılara özellikle Türkiye'ye yalnız olarak gelmiş kadın gezgin ve tatilcilere yönelik araştırmalar yapmaları önerilmektedir. Yapılacak bu tür araştırmalarla Türkiye'de yalnız seyahat eden kadınların seyahatleri sırasında neler yaşadıklarının tespit edilerek Türk kamu otoritesine ve turizm sektör temsilcilerine yönelik öneriler geliştirilebilir.

\section{Kaynakça}

Aitchison, C. (2001), 'Theorizing Other Discourses Of Tourism, Gender And Culture: Can The Subaltern Speak (In Tourism)?' Tourist Studies, 1(2), ss. 133-147.

Altunışık, R., Coşkun, R., Bayraktaroğlu, S. ve Yıldırım, E. (2007), Sosyal Bilimlerde Araştırma Yöntemleri: SPSS Uygulamalı, 5. Baskı, Adapazarı: Sakarya Yayıncılık.

Berdychevsky, L.ve Gibson, H. J. (2015), 'Phenomenology Of Young Women's Sexual Risk-Taking İn Tourism', Tourism Management, 46, ss. 299-310.

Bianchi, C. (2016), 'Solo Holiday Travellers: Motivatorsand Drivers Of Satisfaction and Dissatisfaction', International Journal of TourismResearch, 18(2), ss. 197-208.

Bond, M. (1997), 'Women Travellers: A Newgrowth Market', Retrieved from https://www.hotel-

online.com/News/PressReleases/PataWomenTravellers_Nov1997.html (01-032019).

Carvalho, G., Baptista, M. M. ve Costa, C. (2014), 'Women Travelling Alone: Prospects On Gender and Tourism Experiences', Revista Turismo \& Desenvolvimento, 21/22, ss. 31-32.

Collins, D. ve Tisdell, C. (2002), 'Gender and Differences In Travel Life Cycles', Journal of Travel Research, 41(2), ss. 133-143.

Goodwin, C.ve Lockshin, L. (1992), 'The Solo Consumer: Unique Opportunity For The Service Marketer', Journal of Services Marketing, 6(3), ss. 27-36.

Gray, L. ve Kerstetter, D. (2001), 'What Do University-Educated Women Want From Their Pleasure Travel Experiences?', Journal of Travel Research, 40(1), ss. 4956.

İleri Haber (2019), 'Suudi Kadınlar Erkek Refakatçi olmadan Seyahat Edebilecek', https://ilerihaber.org/icerik/suudi-kadinlar-erkek-refakatci-olmadan-seyahatedebilecek-101407.html (28-10-2019).

Jordan, F.ve Gibson, H. (2005), 'We're Not Stupid...Butwe'll Not Stay Home Either": Experiences Of Solo Women Travelers', Tourism Review International, 9(2), ss. 195-211.

Kaba, B. ve Emekli, G. (2018), 'Turizmde Yükselen Bir Eğilim: Yalnız Seyahat Eden Kadın Gezginler (Türkiye Örneği)', Ege Coğrafya Dergisi, 27 (2), ss. 111-126. 
Khan, S. (2011), 'Gendered Leısure: Are Women More Constraıned In Travel For Leisure?', Tourısmos: An Internatıonal Multıdıscıplınary Journal Of Tourısm, 6(1), ss. 105-121.

Khoo-Lattimore, C. ve Prayag, G. (2015), 'The Girlfriend Getaway Market: Segmenting Accommodation And Service Preferences', International Journal Of Hospitality Management, 45, ss. 99-108.

Kozak, M. (2014), Bilimsel Araştırma: Tasarım, Yazım ve Yayım Teknikleri, 3. Baskı, Ankara: Detay Yayıncılık.

Kümbetoğlu, B. (2005), Sosyolojde ve Antropolojide Niteliksel Yöntem ve Araştırma, 21. Baskı, İstanbul: Bağlam Yayıncılık.

Laesser, C., Beritelli, P. ve Bieger, T. (2009), 'Solo Travel: Explorative İnsights From A Mature Market (Switzerland)', Journal Of Vacation Marketing, 15(3), ss. 217227.

Laing, J.H. ve Crouch, G.I. (2009), 'Lone Wolves? Isolation And Solitude Within The Frontier Travel Experience2 Geografiska Annaler: Series B, Human Geography, 91 (4), ss. 325-342.

Lin, Y. C. ve Lehto, X. Y. (2006), 'A Study Of Female Travelers' Needs Trajectory and Family Life Cycle', Journal Of Hospitality \& Leisure Marketing, 15(1), ss. 65-88.

Marzuki, A., Lay, T., ve Abdul, A. (2012), 'What Women Want: Hotel Characteristics Preferences of Women Travellers', içinde M. Kasımoğlu (Editör), Strategies for Tourism Industry - Micro and Macro Perspectives, ss. 143-165

McNamara, K. E. ve Prideaux, B. (2010), 'A Typology Of Solo İndependent Women Travellers', International Journal Of Tourism Research, 12(3), ss. 253-264.

Media Centre British Airways (2018), '(Don't) Come Fly With Me' https://mediacentre.britishairways.com/pressrelease/details/86/2018-247/10174 (25.10.2019).

Mehmetoglu, M., Dann, G. M. S.ve Larsen, S. (2001), 'Solitary Travellers in the Norwegian Lofoten Islands: Why Do People Travel On Their Own?', Scandinavian Journal Of Hospitality and Tourism, 1(1), ss. 19-37.

Myers, L.M. (2010), Women's Independent Travel Experiences in New Zealand. Yayınlanmamış Doktora tezi, University of Sunderland, Sunderland.

Myers, P. B. ve Moncrief, L. W. (1978), 'Differential Leisure Travel Decision-Making Between Spouses', Annals Of Tourism Research, 5(1), ss. 157-165.

Özdemir, A.A. (2013). Görüşme Kavramının İncelenmesi: Sosyal Hizmetlerdeki Yeri ve Önemi. İçinde, A. A. Özdemir ve Y. Tuna, Görüşme Teknikler,. Eskişehir: Açıköğretim Fakültesi Yayını, ss. 28-47.

Pekiner, A.B. (2019), Yalnız Seyahat Eden Kadınların Motivasyon ve Deneyimleri, Yayınlanmamış Yüksek Lisans Tezi, Batman Üniversitesi, Sosyal Bilimler Enstitüsü, Batman.

Pereıra, A. ve Sılva, (2018), 'Motıvatıons And Experıences Of Women Solo Travellers', Internatıonal Journal Of Multıdıscıplınarıty In Busıness And Scıence, 4(5), ss. 134-138

The Telegraph (2018), 'Why Are So Many Of Us Now Choosing To Travel Alone?' https://www.telegraph.co.uk/travel/comment/whats-behind-the-rise-in-solo-travel/ (25.10.2019).

Tilley, S.ve Houston, D. (2016), 'The Gender Turnaround: Young Women Now Travelling More Than Young Men', Journal Of Transport Geography, 54(June), ss. 349-358.

Tonga, A. (2009), "İranda Kadın Olmak", Odatv.com, https://odatv.com/iranda-kadinolmak-15031956.html, (24-10-2019)

TUYED (2016), 'Yalnız' turist, yalnız değilsin!..' http://www.tuyed.org.tr/yalniz-turistyalniz-degilsin/ (25.10.2019). 
Valaja, E. (2018), Solo Female Travellers' Risk Perceptions and Risk Reduction Strategies - As Expressed in Online Travel Blog Narratives, Yayınlanmamaıs Master Tezi, , Lund University, Department of Service Management and Service Studies, Lund.

Wilson, E. (2004). 'A 'Journey Of Her Own'? The İmpact Of Constraints On Women's Solo Travel'. Yayınlanmamış Doktora tezi, Griffith University, Brisbane, Qld.

Wilson, E. ve Little, D. E. (2005), 'A 'Relative Escape'? The Impact Of Constraints On Women Who Travel Solo', Tourism Review International, 9(2), ss. 155-175.

Wilson, E. ve Little, D. E. (2008), 'The Solo Female Travel Experience: Exploring The 'Geography Of Women's Fear', Current Issues in Tourism, 11(2), ss. 167-186.

Yang, E. C. L., Khoo-Lattimore, C.ve Arcodia, C. (2017), 'A Systematic Literature Review Of Risk and Gender Research In Tourism', Tourism Management, 58(C), ss. 89-100.

Yang, E.C.L., Khoo-Lattimore, C. ve Arcodia, C. (2018), 'Constructing Space And Self Through Risk Taking: A Case Of Asian Solo Female Travelers', Journal Of Travel Research 57(2), ss. 260-272.

Yang, E.C.L., Khoo-Lattimore, C.ve Arcodia, C. (2017b), 'A Narrative Review Of Asian Female Travellers: Looking Into The Future Through The Past' Current Issues In Tourism, 20 (10), ss. 1008-1027. 